\title{
Molecular diagnosis of the curly lettuce parasitic contamination from hydroponic cultivation from supermarkets
}

\author{
Diagnóstico molecular da contaminação parasitária de alface crespa de cultivo \\ hidropônico em supermercados
}

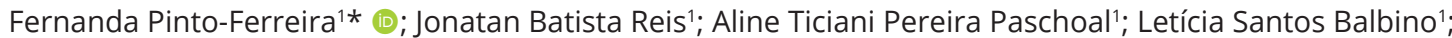
Amanda Bertão-Santos'; ; Juliana Izidoro Lucas'; Monica Tieme Aline Kakimori'; Italmar Teodorico Navarro'; Regina Mitsuka-Breganó ${ }^{1}$
\end{abstract}

' Departamento de Medicina Veterinária Preventiva, Universidade Estadual de Londrina - UEL, Londrina, PR, Brasil

How to cite: Pinto-Ferreira F, Reis JB, Paschoal ATP, Balbino LS, Bertão-Santos A, Lucas Jl, et al. Molecular diagnosis of the curly lettuce parasitic contamination from hydroponic cultivation from supermarkets. Braz J Vet Parasito/ 2020; 29(4): e015820. https:// doi.org/10.1590/S1984-29612020095

\begin{abstract}
The consumption of vegetables has increased in recent years due to the search for a healthier diet that is rich in fiber and has fewer calories. To assess the parasitic contamination of lettuce sold in markets, a survey of parasites was carried out from a supermarket chain in the city of Londrina, Paraná. A total of thirty samples of lettuce were purchased in the ten markets visited, three in each, of which ten were conventionally cultivated, ten were hydroponically cultivated, and ten were organically cultivated. All samples were analyzed using the sedimentation methods of Hoffman, Pons and Janer and the fluctuation method of Faust and colleagues and Willis with adaptations. In addition, the samples were subjected to DNA extraction by a commercial kit and polymerase chain reaction to detect Toxoplasma gondii, Cryptosporidium spp. and Giardia spp., which are protozoa that cause food and waterborne parasitic outbreaks. All samples were negative for sedimentation and flotation techniques. One of the hydroponically cultivated samples was positive for T. gondii. The results demonstrate the risk of curly lettuce contamination from hydroponic cultivation and the need for proper cleaning of these foods before consumption.
\end{abstract}

Keywords: Zoonotic parasites, protozoa, organic cultivation, conventional cultivation.

\section{Resumo}

O consumo de vegetais aumentou nos últimos anos devido à busca de uma dieta mais saudável, rica em fibras e com menos calorias. Para avaliar a contaminação parasitária de alface vendida nos mercados, foi realizado um levantamento de parasitas em vegetais folhosos de uma cadeia de supermercados da cidade de Londrina, Paraná. Um total de 30 amostras foram compradas nos dez mercados visitados, três em cada, dos quais dez foram convencionalmente cultivados, dez cultivados hidroponicamente e dez foram cultivados organicamente. Todas as amostras foram analisadas, usando-se os métodos de sedimentação de Hoffman, Pons e Janer e o método de flutuação de Faust e colaboradores e Willis com adaptações. Além disso, as amostras foram submetidas à extração de DNA por um kit comercial e reação em cadeia da polimerase (PCR) para detectar Toxoplasma gondii, Cryptosporidium spp. e Giardia spp., que são protozoários causadores de surtos transmitidos pela água e alimentos. Todas as amostras foram negativas para técnicas de sedimentação e flutuação. Uma das amostras cultivadas hidroponicamente foi positiva para T. gondii. Os resultados demonstram o risco de contaminação por alface crespa do cultivo hidropônico e a necessidade de limpeza adequada desses alimentos antes do consumo.

Palavras-chave: Parasitas zoonóticos, protozoários, cultivo orgânico, cultivo convencional. 
The consumption of green leafy vegetables promotes numerous health benefits related to the reduction of weight gain and chronic diseases, such as hypertension and diabetes. In Brazil, curly lettuce (Lactuca sativa) is among the most cultivated leafy vegetables, and because they are often consumed raw, they are important routes of transmission of pathogens, such as parasites. In recent years, an increasing number of foodborne parasitic outbreaks have been associated with the consumption of leafy vegetables and fruits, with the main reported parasites being Toxoplasma gondii (Pinto-Ferreira et al., 2019a, c), Cryptosporidium spp. (Millard et al., 1994), and Giardia spp. (Mintz et al., 1993), among others.

Lettuce is grown mainly using conventional methods and organic and hydroponic systems. The conventional method is characterized by the cultivation of lettuce in the soil using fertilizers and pesticides, which are mainly of a chemical nature. The hydroponic method is characterized by cultivation in an aqueous solution with dissolved nutrients and chemical fertilizers. Organic agriculture has also emerged as an alternative to conventional agriculture, excluding the use of pesticides, agrochemicals, synthetic fertilizers, growth regulators or other chemical contaminants (Bezerra \& Barreto, 2011/2012).

Vegetables can be contaminated during cultivation, harvest, or distribution. The objective of the work was to evaluate the parasitic contamination of curly lettuce from conventional, hydroponic, and organic cultivation sold in a supermarket chain in the city of Londrina, northern Paraná, Brazil.

This research was conducted in accordance with the criteria and requirements of the Human Ethics of Universidade Estadual de Londrina (UEL) and approved under protocol 2,481,228.

Londrina $\left(23^{\circ} 18^{\prime} 36^{\prime \prime} \mathrm{S}\right.$ and $\left.51^{\circ} 09^{\prime} 46^{\prime \prime} \mathrm{W}\right)$ is considered the primary city of a metropolitan area and is the second largest city in the state of Paraná, located in southern Brazil. The estimated population is 569,733 inhabitants. The study was carried out in a supermarket chain in the municipality (Figure 1) which were fictionally named A, B, $D, E, F, G, H, I$, and J.
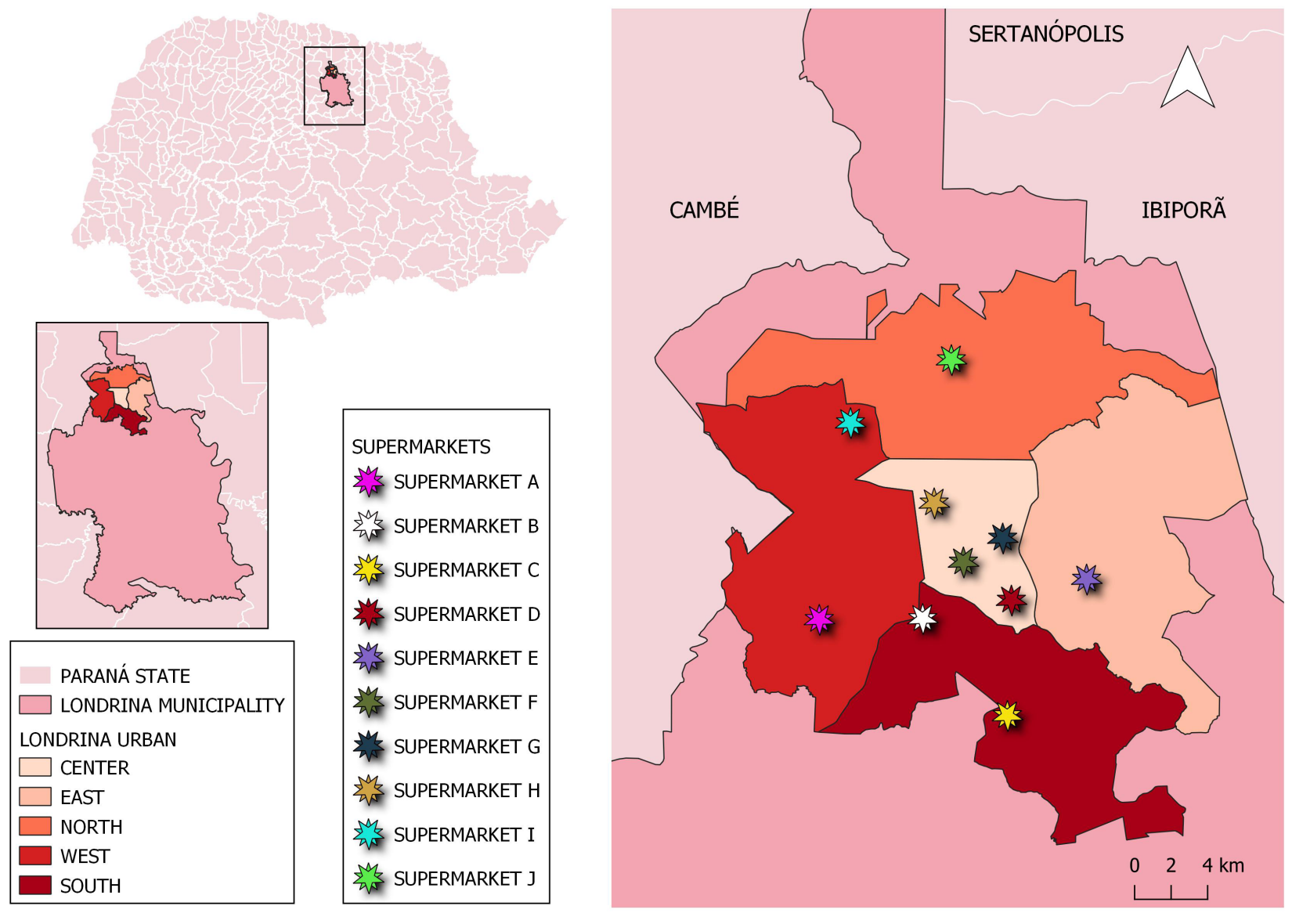

Figure 1. Map of Paraná with emphasis on the city of Londrina and distribution of supermarkets, in which the curly lettuce samples were purchased and submitted to parasitological research, from February to April 2019, Paraná, Brazil. 
Supermarkets of the same chain were visited, and in each one, three lettuce clusters were purchased, one conventionally cultivation, one hydroponically cultivated, and one organically cultivated. The clusters were packed in first-use plastic bags, identified and kept refrigerated until processing.

Using the protocol proposed by Ferreira et al. (2018), with adaptations, $50 \mathrm{~g}$ of leaves from each sample was homogenized with $150 \mathrm{~mL}$ of $1 \mathrm{M}$ glycine extraction solution in a plastic bag under manual agitation for 10 minutes. After homogenization, $50 \mathrm{~mL}$ of the extract was placed in a sedimentation cup to perform the Hoffmann, Pons \& Janer (Hoffmann et al., 1934) method, while the remainder was distributed in two $50 \mathrm{~mL}$ conical bottom tubes subjected to double centrifugation at $2100 \times \mathrm{g}$ for 10 minutes. One of the tubes subjected the sediment to the flotation techniques of Faust et al. (1939) and Willis (1921), while the other tube was aliquoted in a $1.5 \mathrm{~mL}$ microtube and stored at $-20^{\circ} \mathrm{C}$ until DNA extraction. The parasitic structures were observed with an Olympus BX43 optical microscope (Shinjuku, Tokyo, Japan).

DNA extraction was performed using the Nucleospin Tissue ${ }^{\circledR}$ commercial kit (Macherey-Nagel, Düren, Germany) according to the manufacturer's recommendations. Previous cycles of freezing $\left(-80^{\circ} \mathrm{C}\right)$ and thawing $\left(56^{\circ} \mathrm{C}\right)$ were included to encourage the rupture of the cysts and oocysts in the samples. The extraction products were stored at $-20^{\circ} \mathrm{C}$ until PCR (polymerase chain reaction) processing for Toxoplasma gondii, Cryptosporidium spp. and Giardia spp.

To detect T. gondii DNA, a 529 bp fragment was amplified using primers described by Homan et al. (2000). To detect Cryptosporidium spp. a nested PCR was performed with the target gene $18 \mathrm{~S}$ rRNA between 826 and $840 \mathrm{bp}$ (Xiao et al., 1999). To detect Giardia spp., the samples were submitted to a nested PCR to amplify the fragment of approximately $300 \mathrm{bp}$ of the $18 \mathrm{~S}$ gene of Giardia spp. (Coklin et al., 2007). PCR products were visualized after electrophoresis on a 1.5\% agarose gel stained with $\mathrm{SyBr}$ safe DNA (Invitrogen ${ }^{\circledR}$, California, USA).

The Epilnfo 3.5.4 program (CDC, Atlanta, Georgia, USA) was used to tabulate the variables with the parasitic and molecular results found. Univariate statistical frequency analysis was performed using the Epilnfo 3.5.4 program.

A total of ten supermarkets were visited, totaling 30 samples, ten of which were conventionally cultivated, ten were hydroponically cultivated, and ten were organically cultivated. All samples were negative in the flotation and sedimentation techniques. During the molecular analysis for the detection of Cryptosporidium spp., Giardia spp. and $T$. gondii, a hydroponically cultivated sample from supermarket C had an amplification of the 529 bp DNA fragment of $T$. gondii.

Contamination of vegetables by parasites has been previously described in articles worldwide (Millard et al., 1994; Ahmad et al., 2016; Balarak et al., 2016; Lass et al., 2019). Pinto-Ferreira et al. (2019b) evaluated vegetables from organically cultivated gardens and observed the presence of parasites in $45.23 \%$ (19/21) of the analyzed samples, with species of the genus Chilomastix, Dipylidium, Entamoeba, Strongyloides and Trichuris being the most frequent. It is possible that the vegetables collected in the garden were more contaminated when compared to those for sale because before being marketed, vegetables are rinsed, which, when properly carried out using running water, can help reduce contamination by parasites.

In Florianópolis, Santa Catarina, Brazil, Soares \& Cantos (2006) evaluated the presence of parasites in 750 vegetables from supermarkets, grocery stores and street markets and demonstrated high percentages of contamination, most frequently in watercress (Nasturtium officinale). The authors believe that the structure of this vegetable facilitates its degree of contamination since they have multiple and separate leaves, with a large contact area, allowing greater adhesion of certain enteroparasites (Soares \& Cantos, 2005). In the present study, curly lettuce was the only vegetable evaluated, which may have favored the absence of helminth contamination in all samples. Studies that comparatively evaluate contamination in different types of vegetables are extremely important.

A study carried out in vegetable gardens in the municipalities of Apucarana, Marilândia do Sul, Ortigueira, Rolândia and Londrina, in the state of Paraná, observed the presence of protozoa such as T. gondii (12.9\%), Cryptosporidium parvum (11.3\%) and Giardia intestinalis (25.8\%) in organic vegetables. Organic cultivation has steps that can favor contamination, such as fertilization, irrigation, and rinsing (Ferreira et al., 2018). However, in the present study, these steps did not promote contamination in either organic or conventional cultivation.

Hydroponic cultivation reduces many critical points of contamination since nutrients are diluted in water, the planting site is generally better controlled, there is no access for animals, and there is no contact with soil (Bezerra \& Barreto, 2011/2012). The expected result was that the hydroponic samples would all be negative for parasites. However, a hydroponic sample was positive for T. gondii. At the end of cultivation, in any type of planting, vegetables are rinsed. When carried out under running water, this step increases the shelf life of the food because it reduces the temperature after harvest and dirt. However, water quality and the use of a rinse tank can lead to contamination 
of vegetables, even after proper and sanitary cultivation (Ferreira et al., 2018). It is possible that this is the cause of the contamination of the sample found in this study. Marchioro et al. (2016), in a study in Maringá, Paraná, Brazil, analyzed 238 samples of raw vegetables for consumption, among which they detected a rocket sample for $T$. gondii and suggested that the contamination may occur during commercialization.

Toxoplasmosis is a zoonosis caused by the protozoan $T$. gondii and is of great importance in public health, as it causes miscarriages, congenital malformations, and severe nonspecific signs in immunosuppressed patients (Dubey, 2010). The route of transmission of the agent is variable; however, eating habits are determinants of the epidemiology of the disease. Vegetation contamination by the parasite has been reported in other studies (Ahmad et al., 2016; Lass et al., 2019) and has been noted as the most common possible route of transmission of toxoplasmosis outbreaks in the future (Pinto-Ferreira et al., 2019a).

The vegetables in the study, in addition to presenting a risk of contamination during planting, may have been contaminated due to the improper and unsanitary handling of vegetables during commercialization. First, exposure favors manipulation and leaves food susceptible to aerosols. Another important and common contamination point in these establishments is related to the habit of employees spraying water on vegetables to keep them soft and fresh; if contaminated water is used, then the food be contaminated (Balarak et al., 2016).

This study demonstrates the risk of hydroponic cultivation causing contamination of vegetables that are consumed raw. There is no type of safe cultivation, but the processing of vegetables using proper management is important in all stages. In addition, it is important to emphasize that the quality of the irrigation and rinse water is essential for maintaining the innocuousness of leafy vegetables, whether of hydroponic origin or other type of cultivation, moreover, using hygienic measures at home is essential for increasing the safety of consumed food.

\section{References}

Ahmad SO, El Fadaly HA, Zaki MS, Barakat AMA. Incidence of zoonotic parasites in egyptian raw vegetable salads. Life SciJ 2016; 13(2): 27-31. http://dx.doi.org/10.7537/marslsj13021605.

Balarak D, Ebrahimi M, Modrek MJ, Bazrafshan E, Mahvi AH, Mahdavi Y. Investigation of parasitic contaminations of vegetables sold in markets in the city of Tabriz in 2014. Glob J Health Sci 2016; 8(10): 54811. http://dx.doi.org/10.5539/gjhs.v8n10p178. PMid:27302434.

Bezerra E No, Barreto LP. As técnicas de hidroponia. An Acad Pernambucana Ciênc Agronômica 2011/2012; 8-9: $107-137$.

Coklin T, Farber J, Parrington L, Dixon B. Prevalence and molecular characterization of Giardia duodenalis and Cryptosporidium spp. in dairy cattle in Ontario, Canada. Vet Parasitol 2007; 150(4): 297-305. http://dx.doi.org/10.1016/j.vetpar.2007.09.014. PMid:17964724.

Dubey JP. Toxoplasmosis of animals and humans. 2nd ed. Maryland, USA: CRC Press; 2010.

Faust EC, Sawitz W, Tobie J, Odom V, Peres C, Lincicome DR. Comparative efficiency of various technics for the diagnosis of protozoa and helminths in feces. J Parasitol 1939; 25(3): 241-262. http://dx.doi.org/10.2307/3272508.

Ferreira FP, Caldart ET, Freire RL, Mitsuka-Breganó R, Freitas FM, Miura AC, et al. The effect of water source and soil supplementation on parasite contamination in organic vegetable gardens. Rev Bras Parasitol Vet 2018; 27(3): 327-337. http://dx.doi.org/10.1590/ s1984-296120180050. PMid:30183998.

Hoffmann WA, Pons JA, Janer JL. Sedimentation concentration method in schistosomiasis, Puerto Rico. J Public Health 1934; 9: 283-298.

Homan WL, Vercammen M, De Braekeleer J, Verschueren H. Identification of a 200- to 300-fold repetitive 529 bp DNA fragment in Toxoplasma gondii, and its use for diagnostic and quantitative PCR. Int J Parasito/ 2000; 30(1): 69-75. http://dx.doi.org/10.1016/ S0020-7519(99)00170-8. PMid:10675747.

Lass A, Ma L, Kontogeorgos I, Zhang X, Li X, Karanis P. First molecular detection of Toxoplasma gondii in vegetable samples in China using qualitative, quantitative real-time PCR and multilocus genotyping. Sci Rep 2019; 9(1): 17581. http://dx.doi.org/10.1038/ s41598-019-54073-6. PMid:31772319.

Marchioro AA, Tiyo BT, Colli CM, de Souza CZ, Garcia JL, Gomes ML, et al. First detection of Toxoplasma gondii DNA in the fresh leafs of vegetables in South America. Vector Borne Zoonotic Dis 2016; 16(9): 624-626. http://dx.doi.org/10.1089/vbz.2015.1937. PMid:27421086.

Millard PS, Gensheimer KF, Addiss DG, Sosin DM, Beckett GA, Houck-Jankoski A, et al. An outbreak of cryptosporidiosis from fresh-pressed apple cider.JAMA 1994; 272(20): 1592-1596. http://dx.doi.org/10.1001/jama.1994.03520200048034. PMid:7966869. 
Mintz ED, Hudson-Wragg M, Mshar P, Cartter ML, Hadler JL. Foodborne giardiasis in a corporate office setting. J Infect Dis 1993; 167(1): 250-253. http://dx.doi.org/10.1093/infdis/167.1.250. PMid:8418177.

Pinto-Ferreira F, Caldart ET, Pasquali AKS, Mitsuka-Breganó R, Freire RL, Navarro IT. Patterns of transmission and sources of infection in outbreaks of human toxoplasmosis. Emerg Infect Dis 2019a; 25(12): 2177-2182. http://dx.doi.org/10.3201/ eid2512.181565. PMid:31742524.

Pinto-Ferreira F, Freire RL, Caldart ET, Paschoal ATP, Arias GB, Ladeia WA, et al. Organic horticulture: a current demand, whose proper management is the only guarantee of safe food. Biotemas 2019b; 32(3): 43-50. http://dx.doi.org/10.5007/21757925.2019v32n3p43.

Pinto-Ferreira F, Mitsuka-Breganó R, Monica TC, Martins FDC, Matos RLN, Mareze M, et al. Investigation and environmental analysis of samples from outbreak of toxoplasmosis at research institution in Londrina, Paraná, Brazil, 2016. Rev Bras Parasitol Vet 2019c; 28(3): 518-521. http://dx.doi.org/10.1590/s1984-29612019044. PMid:31482939.

Soares B, Cantos GA. Detecção de estruturas parasitárias em hortaliças comercializadas na cidade de Florianópolis, SC, Brasil. Rev Bras Ciênc Farm 2006; 42(3): 455-460. http://dx.doi.org/10.1590/S1516-93322006000300015.

Soares B, Cantos GA. Qualidade parasitológica e condições higiênico-sanitárias de hortaliças comercializadas na cidade de Florianópolis, Santa Catarina, Brasil. Rev Bras Epidemio/ 2005; 8(4): 377-384. http://dx.doi.org/10.1590/S1415-790X2005000400006.

Willis HH. A simple levitation method for the detection of hookworm ova. Med J Aust 1921; 2(18): 375-376. http://dx.doi. org/10.5694/j.1326-5377.1921.tb60654.x.

Xiao L, Escalante L, Yang C, Sulaiman I, Escalante AA, Montali RJ, et al. Phylogenetic analysis of Cryptosporidium parasites based on the small-subunit rRNA gene locus. App/ Environ Microbio/ 1999; 65(4): 1578-1583. http://dx.doi.org/10.1128/AEM.65.4.15781583.1999. PMid:10103253. 